\title{
Pendekatan Sufistik Dalam Sistem Pendidikan Islam Di Perguruan Tinggi Studi Fenomenologis Program Pencerahan Kalbu di Pesantren Mahasiswa UMI Dar al-Mukhlisin Labbakkang Pangkep
}

\author{
Afifuddin \\ Universitas Islam Negeri Alauddin Makassar \\ afifuddinbrs@gmail.com
}

\begin{abstract}
The purpose of this study was to to understand the relevance of Sufism with Islamic education and its application as a method and approach of moral-spiritual education islamic college through Heart Enlightenment Program in Islamic Boarding of UMI Makassar Labbakkang. The method used in this reseach is qualitative descriptive with phenomemological approach, the methods of collecting the data were observation, interview and study documents. Reseach findings showed that Islamic education emphasizes on attainment of esoteric quality as a part of human dimension. So that, one of effective methods wich is expected to support the achievement of this aim is sufistic approach. In this case, Sufistic education conducts paedagogical contruction through method of takhalli, tahalli and tajalli.
\end{abstract}

Keywords: Sufism, Islamic Education, College, Islamic Boarding School

\begin{abstract}
Abstrak
Penelitian ini bertujuan untuk memahami keterkaitan sufisme dengan pendidikan Islam serta penerapannya sebagai metode dan pendekatan pendidikan moral-spiritual di lingkungan perguruan tinggi Program Pencerahan Kalbu Pesantren Mahasiswa UMI Makassar di Labbakkang. Penelitian ini menggunakan metode kualitatif deskriptif dengan pendekatan fenomemologis, teknik pengumpulan data dilakukan dengan observasi, wawancara dan studi dokumen. Temuan penelitian adalah pendidikan islam menekankan pencapaian kualitas esoteris sebagai bagian dari dimensi manusia. Sehingga, salah satu metode efektif yang diharapkan dapat menunjang tercapainya tujuan ini adalah pendekatan sufistik. Dalam hal ini, pendidikan sufistik melakukan konstruksi paedagogis melalui metode takhalli, tahalli dan tajalli.
\end{abstract}

Kata Kunci: Sufistik, Pendidikan Islam, Perguruan Tinggi, Pesantren

Permalink/DOI:http://dx.doi.org/10.18326/infsl3.v11i1.75-96 


\section{Pendahuluan}

Pendidikan secara umum bertujuan mencetak dan membangun manusia Indonesia seutuhnya. Dalam hal ini dipahami bahwa pendidikan, khususnya pendidikan agama, tidak hanya menyiapkan manusia yang unggul dari segi intelektualitasnya saja, namun lebih dari itu pendidikan berupaya seoptimal mungkin membangun manusia berkepribadian dan memiliki integritas kejiwaan. Hal itulah yang mendasari adanya konsep pembelajaran agama di semua jenjang pendidikan. Tanpa bekal pengetahuan dan bimbingan keagamaan, mustahil membangun manusia Indonesia yang berkualitas sebagaimana yang dicita-citakan.

Beranjak dari konsepsi pendidikan secara umum, disepakati bahwa setidaknya ada tiga aspek pencapaian tujuan pendidikan, yaitu aspek kognisi, afeksi dan psikomotorik. Aspek kognisi melakukan pembelajaran dengan menitikberatkan pada proses transfer ilmu pengetahuan sebanyak mungkin kepada anak didik. Tercapainya tujuan dari aspek ini dapat diukur dengan kemampuan anak didik dalam memahami dan menguasai teori-teori ilmu pengetahuan secara rasional. Aspek afeksi adalah salah satu upaya pendidikan yang menekankan pada pemahaman terhadap nilai-nilai dan sikap moral anak didik. Meski tidak mengesampingkan aspek kognisi, internalisasi nilai-nilai agama dilakukan secara intensif dan dominan. Yang ketiga adalah psikomotorik, yaitu kemampuan dalam pengamalan (skill) dan pengaplikasian nilai-nilai agama dalam kehidupan sehari-hari.

M. Amin Abdullah (1998: 56) secara intens menekankan pencapaian target afektif dan psikomotorik sebagai tahapan penting yang harus dicapai dalam proses pendidikan Islam. Menurutnya, meskipun aspek afeksi sangat terkait erat dengan aspek kognisi, namun dalam bidang pendidikan agama aspek kedua ini (afeksi) perlu lebih diutamakan daripada yang kedua. Khususnya aspek psikomotorik, aspek ini lebih menekankan kemampuan anak didik untuk dapat menumbuhkan motivasi dalam diri sendiri sehingga dapat menggerakkan, menjalankan dan mentaati nilai-nilai dasar agama yang telah diinternalisasikan dalam dirinya sendiri lewat tahap afeksi. 
Dari sini tampak bahwa pengetahuan agama yang diperoleh dari lewat jalur pendidikan jauh berbeda dari jenis pengetahuan lainnya yang juga diperoleh lewat jalur pendidikan. Pengetahuan agama tidak boleh hanya berhenti dan terbatas pada wilayah kognisi, seperti lazim terjadi pada bidang-bidang studi tertentu. Keberhasilan pendidikan agama harus tercermin pada tindakan individu dan tindakan sosial yang konkret dalam kehidupan individu, keluarga dan masyarakat.

Namun ironisnya, di saat menjamurnya institusi dan kegiatan keagamaan, baik di jalur formal, informal dan media elektronika, berbagai bentuk kebrutalan, kriminalitas, premanisme dan penyimpangan moral, utamanya pada generasi muda, menjadi realitas dan pemandangan yang sulit ditutup-tutupi. Realitas krusial ini pulalah yang memancing munculnya asumsi bahwa pendidikan Islam secara khusus, dan pendidikan agama secara umum, telah gagal dalam mencapai tujuannya. Sikap apriori dan pesimistik semakin menguatkan anggapan ajaran moralitas agama tidak berdaya menghadapi terpaan gelombang globalisasi dan modernisasi.

Para pakar dan praktisi pendidikan Islam telah sejak lama mengerahkan perhatian dan pemikiran mereka guna menemukan suatu formulasi pendidikan alternatif, di samping metode konvensional dan formalistik yang diaplikasikan pada institusiinstitusi pendidikan yang ada. Problem yang paling mendasar adalah bahwa perkembangan kependidikan senantiasa tertinggal jauh dari perkembangan serta pergeseran nilai yang terjadi di dalam masyarakat. Pendidikan Islam, yang diwakili oleh institusi madrasah, pesantren dan PTAI tentunya menghadapi beban sekaligus tantangan yang cukup besar dalam merespon realitas sosial tersebut.

Problematika dilematis menjadi semakin rumit dengan adanya intervensi budaya-budaya asing, yang disadari ataupun tidak, sangat berpengaruh terhadap perilaku dan pola hidup generasi muda. Sistem pendidikan Islam yang masih diwarnai oleh tendensi birokratisasi dan tidak tersedianya kurikulum pembelajaran yang efektif membawa dampak ketidakpercayaan masyarakat terhadap institusi pendidikan Islam.

Di tengah berbagai tudingan dan tantangan tersebut, salah satu 
perguruan tinggi agama yang cukup terkemuka di Indonesia Timur, Universitas Muslim Indonesia Makassar, cukup intens memikirkan upaya-upaya pembelajaran keagamaan kepada mahasiswa, utamanya mahasiswa muslim. UMI merupakan salah satu perguruan tinggi agama (PTAI) yang melaksanakan sistem pendidikan yang mengintegrasikan ilmu-ilmu umum dengan ilmu agama. Di samping mencetak sarjana di bidang agama melalui Fakultas Agama Islamnya, UMI berupaya menelorkan sarjana-sarjana di berbagai bidang non-agama yang memiliki kesadaran dan pemahaman agama yang benar dan utuh.

Premanisme kampus, tawuran antar mahasiswa, narkoba dan pergaulan bebas merupakan fenomena umum yang terjadi hampir di setiap kehidupan kampus. Bahkan PTAIN dan PTAIS, yang nota bene merupakan media yang sangat vital dalam membangun masyarakat intelektual yang memiliki komitmen religius yang tinggi, tidak luput dari fenomena di atas. Tampaknya ada kesenjangan antara intensitas pangajaran materi-materi agama di perguruan tinggi dan realitas krisis moral yang terjadi dalam kehidupan kampus.

Berangkat dari fenomena dan problematika tersebut, UMI mencoba membuka terobosan 'baru' dengan melakukan pembinaan khusus terhadap setiap mahasiswa, baik dari fakultas agama maupun non-agama, yaitu melalui program Pencerahan Kalbu. Dengan pendekatan spiritual-sufistik, UMI melakukan pembinaan, pendidikan dan bimbingan moral keagamaan kepada mahasiswa, dengan tujuan agar mereka tidak semata-mata mengetahui agamanya secara kognitif, tapi juga memiliki kesadaran afektif dan psikomotorik untuk mengaplikasikan nilai-nilai moral keagamaan tersebut dalam kehidupan sehari-hari.

Dalam kerangka perkembangan dan dinamisasi paradigma pendidikan Islam, sangat diperlukan upaya dan terobosan positif dan berkesinambungan, bukan hanya pada materi dan sarana pendidikan, namun yang kalah pentingnya adalah metode pendekatan dalam menginternalisasi nilai-nilai moral kepada anak didik. Berangkat dari pemikiran di atas, metode Pencerahan Kalbu yang diterapkan UMI merupakan hal yang cukup penting dan menarik untuk diteliti. 


\section{Spiritualitas sebagai Konsep Dasar Pendidikan Islam}

Jika disepakati bahwa pendidikan adalah suatu proses, maka proses tersebut akan berakhir pada tercapainya tujuan akhir pendidikan. Suatu tujuan yang hendak dicapai oleh pendidikan pada hakikatnya adalah suatu perwujudan dari nilai-nilai ideal yang terbentuk dalam pribadi manusia yang diinginkan.

Hal yang sama ditegaskan oleh H.M. Arifin (2000: 122), bahwa pendidikan Islam, di samping bertugas menginternalisasikan (menanamkan dalam pribadi) nilai-nilai islami, juga mengembangkan anak didik agar mampu melakukan pengamalan nilai-nilai itu secara dinamis dan fleksibel dalam batas-batas konfigurasi idealitas wahyu. Dapat dipahami bahwa untuk mewujudkan target ideal tersebut tidak semestinya mengandalkan pendekatan kognitif semata, namun dimensi afektif dan psikomotorik harus mendapatkan porsi perhatian yang lebih besar.

Berkaitan dengan pendekatan metodologis dalam proses pendidikan, Abbas Mahjub (1987: 181) dalam bukunya Ushul alFikr al-Tarbawiy fi al-Islam cenderung meninjaunya dari sudut pandang dualisme kemanusiaan. Menurutnya, konsep pendidikan Islam memandang manusia dalam dua aspek, yaitu aspek lahiriah dan aspek ruhaniah (spiritual). Kedua aspek tersebut tidak dapat dipisahkan satu sama lain, di mana keduanya saling terkait dan membutuhkan pengembangan yang optimal. Karena itu, pendidikan Islam bertugas menciptakan keseimbangan antara kedua aspek, dengan mengingat bahwa ruh atau spirit manusia merupakan unsur penting dalam pembentukan keimanan dan ketakawaan dalam jiwa manusia.

Pendekatan sufistik dipahami sebagai suatu pendekatan kependidikan yang, tidak sekedar mengadopsi konsep-konsep tasawuf dan menerapkannya sebagai satu metode dalam proses pendidikan, tapi ia juga merupakan paradigma religiositas yang mengangkat aspek esoteris (batiniah) agama sebagai aspek utama yang seringkali dikesampingkan. Hal tersebut didasarkan pada keberadaan dan hakikat ajaran Islam sendiri yang meliputi dua aspek pokok; eksoteris (dzahir) dan esoteris (bathin). 
Postulasi di atas semakin menegaskan bahwa pendidikan Islam semestinya mengupayakan pendekatan yang lebih efektif dalam merespon gejala-gejala dan kasus-kasus penyimpangan moral yang mulai mewabah di kalangan generasi muda, khususnya mahasiswa. Muhaimin (2002: 79), dalam bukunya Paradigma Pendidikan Islam, menghimbau perlunya mencermati kembali berbagai indikator kegagalan PAI di sekolah dan perguruan tinggi, serta mencari solusi lewat pengembangan strategi dan pendekatan pendidikan Islam yang diorientasikan kepada pendidikan nilai (afeksi).

\section{Pesantren dan Tasawuf}

Problematika sosial yang multi dimensi dan terpuruknya tingkat kualitas pendidikan di Indonesia mengakibatkan munculnya sikap pesimistik terhadap dunia pendidikan formal. Persoalan tidak dianggap selesai dengan penekanan pada kualitas kognitif semata, tapi masyarakat masih menuntut peranan lembaga pendidikan dalam meluruskan moral perilaku anak didiknya. Salah satu institusi dan pola pendidikan yang mulai dilirik adalah pesantren.

Pesantren merupakan salah satu jenis pendidikan Islam Indonesia yang bersifat tradisional untuk mendalami ilmu agama Islam, dan mengamalkannya sebagai pedoman hidup keseharian, atau disebut tafaqquh fi al-din, dengan menekankan pentingnya moral dalam hidup bermasyarakat. Pesantren telah hidup sejak 300-400 tahun yang lampau, menjangkau hampir seluruh lapisan masyarakat muslim (Mastuhu, 1994:3). Pesantren telah diakui sebagai lembaga pendidikan yang telah ikut serta mencerdaskan kehidupan bangsa. Terutama di zaman kolonial, pesantren merupakan lembaga pendidikan yang sangat berjasa bagi umat Islam.

Dalam masa sekitar abad ke-18-an, nama pesantren sebagai lembaga pendidikan rakyat terasa sangat berbobot terutama dalam bidang penyiaran agama. Kelahiran pesantren baru selalu diawali dengan cerita "perang nilai" antara pesantren yang akan berdiri dengan masyarakat sekitarnya, dan diakhiri dengan kemenangan pihak pesantren. Selanjutnya pesantren dapat diterima untuk hidup 
di masyarakat dan kemudian menjadi panutan bagi masyarakat sekitarnya dalam bidang kehidupan moral

Nilai baru yang dibawa pesantren tersebut, untuk mudahnya disebut 'nilai putih' yaitu nilai-nilai moral keagamaan. Sedang nilai lama yang lebih dulu ada di dalam masyarakat disebut 'nilai hitam', yaitu nilai-nilai rendah dan tidak terpuji seperti mencuri, minum minuman keras, narkotika dan sebagainya (Mastuhu, 1994:3). Jika dikaitkan dengan perkembangan dan pergeseran nilai yang terjadi dewasa ini, tampaknya keberadaan pesantren pada skala makro semakin dibutuhkan.

Kehadiran pesantren di tengah masyarakat tidak hanya sebagai lembaga pendidikan, tetapi juga sebagai lembaga penyiaran agama dan kegiatan sosial keagamaan. Di lain pihak, jika dibandingkan dengan lembaga-lembaga pendidikan umum, pesantren ternyata memiliki karakteristik tersendiri yang menjadi daya tarik tertentu, khususnya pada masyarakat bawah.

Menurut hasil pengamatan Karel A. Steenbrink (1984: 1-9), sejak zaman kolonial pesantren lebih menekankan orientasinya pada pembinaan moral dalam konteks ukhrawi, sementara orientasi sekolah umum diarahkan untuk meningkatkan kecerdasan dan keterampilan dalam konteks hidup keduniawian. Namun dalam perkembangannya, meski pembinaan moral masih merupakan misi utamanya, pesantren telah menjadi lembaga pendidikan yang memberikan materi umum dan agama secara berimbang. Hal itu membuktikan kelenturan pesantren dalam merespon perkembangan dan tuntutan masyarakat.

Kaitan antara pesantren dan tasawuf tidaklah terlalu sulit mencarinya. Hal ini dikarenakan bahwa selain keduanya secara sosiologis memiliki persamaan-persamaan, misalnya keduanya sama-sama dapat dilihat sebagai subkultur masyarakat Indonesia, dan Jawa khususnya. Pada sisi lain, tasawuf merupakan subkultur dalam Islam. Dikatakan bahwa pesantren adalah subkultur dalam masyarakat Indonesia karena itu sudah menajdi bagian budaya bangsa Indonesia.

Memperhatikan praktek-praktek sufistik yang berlaku di pesantren, dapat dikatakan bahwa tasawuf yang dipraktekkan di 
pesantren memiliki ciri khas tersendiri. Tasawuf yang berkembang adalah tasawuf yang memiliki nilai-nilai praktis yang tinggi. Sedangkan aspek esoteris idealnya tidak begitu dipentingkan. Karena itulah tasawuf yang berkembang di pesantren tidak mengenal praktek pemunculan perasaan bersatunya diri dengan Tuhan atau perasaan-perasaan ekstasi lainnya (mistical ecstacy) dalam rangka menganal Tuhan. Sebaliknya, tasawuf yang dikembangkan adalah yang memiliki aspek-aspek praktis yang dapat dipraktekkan dalam kehidupan sehari-hari manusia, yang biasa disebut "tasawuf dunia". Dengan demikian aspek spekulatifnya dicoba untuk sedapat mungkin diminimalkan, atau bahkan dihilangkan sama sekali. Aspek-aspek praktis itu misalnya berakhlak mulia dan berbudi luhur, berbuat baik kepada seluruh manusia, rendah hati, ikhlas, mudah menolong dan sebagainya. Dengan demikian tasawuf yang berkembang di pesantren adalah tasawuf yang berdimensi kemanusiaan atau tasawuf empiris.

\section{Metode Penelitian}

Dalam rangka pemecahan masalah dan pencapaian tujuan penelitian di atas, peneliti menggunakan metode kualitatif deskriptif dengan pendekatan fenomemologis. Teknik pengumpulan data dilakukan dengan observasi atau pengamatan langsung, wawancara mendalam dan studi dokumen.

\section{Analisis}

\section{Pencerahan Kalbu dan Pembentukan Karakter Islami}

Sebagai Perguruan Tinggi Agama yang cukup terkemuka di Indonesia Timur, UMI memiliki idealisme menciptakan sarjana yang ulama, dalam artian memiliki ilmu agama yang memadai, dan ulama yang sarjana, yaitu ahli agama yang memiliki pondasi ilmu pengetahuan umum. Dengan kata lain, UMI berupaya menciptakan out-put yang integralistik, yaitu manusia terdidik yang memiliki kekuatan ilmu dan iman secara integral. Kapabilitas keilmuan bukan sepenuhnya standar keberhasilan seorang alumnus UMI, tapi harus ditunjang dengan kualitas moral dan akhlak sebagai indikator tertanamnya pendidikan agama dalam dirinya. 
Dalam mencapai cita-cita dan misi penyelenggaraan kependidikannya, UMI mengalami kendala dan problematika yang cukup memprihatinkan. Tawuran antar mahasiswa, kenakalan dan premasnisme kampus serta pergaulan bebas yang sulit dikendalikan. Belum lagi persoalan suasana keagamaan yang belum sepenuhnya mewarnai lingkungan kampus dan civitas akademika. Kemampuan baca tulis al-Qur'an dan kualitas pengamalan ibadah yang rata-rata sangat minim merupakan salah satu kendala utama terwujudnya 'Kampus Islami' yang dicita-citakan UMI.

Persoalan-persoalan akademik tersebut sejak lama telah menggelisahkan menjadi keprihatinan internal dalam keluarga UMI. Hal tersebut mendorong jajaran pimpinan dan pembina UMI berpikir dan berupaya mencari jalan keluar yang dianggap paling efektif. Akhirnya pada tahun 1999 tercapai kesepakatan bersama untuk memulai langkah baru sebagai alternatif dalam rangka pembinaan kemahasiswaan. Satu program yang dipandang cukup efektif untuk menangani persoalan-persoalan di atas diluncurkan seiring dengan masuknya tahun akademik 2000-2001. Program pembinaan tersebut dinamakan Pencerahan Kalbu.

Menurut H. Abd. Rahim Amin, Pengasuh Pesantren Mahasiswa UMI, program Pencerahan Kalbu tersebut dianggap sebagai program unggulan dan crash program. Program unggulan dimaksudkan sebagai program yang menggunakan metode yang relevan dengan situasi yang ada dan sekaligus sebagai alternatif ideal untuk menangani problematika moral mahasiswa dan seganap civitas akademika. Dan ternyata dalam perkembangannya, program ini mendapat perhatian dan dukungan yang besar dari masyarakat dan khususnya para orang tua mahasiswa. Dengan program khusus tersebut, mereka memiliki harapan besar agar anak-anak mereka dapat terdidik dengan baik. Bukan hanya pada kualitas keilmuan mereka, tapi juga yang sangat penting adalah pembinaan dan pembentukan kepribadian yang dilandasi ajaran agama.

Program Pencerahan Kalbu sebagai crash program, dalam arti bahwa pada intinya program pembinaan ini diarahkan pada penanaman ajaran akidah, syariah dan akhlak secara 'cepat dan terpadu atau sinergi'. Materi pendidikan agama yang diberikan 
secara formal di ruang kuliah pada dasarnya hanya memperkenalkan dan mensosialisasikan konsep-konsep agama kepada mahasiswa. Materi-materi tersebut pada kenyataannya tidak dapat diharapkan untuk memberikan penyadaran sekaligus penanaman nilai-nilai agama kepada mahasiswa.

Di samping itu, materi-materi yang diberikan pada posisinya sebagai mata kuliah dasar reguler tidak memperlihatkan sinergitas antara konsep-konsep akidah, syariah dan akhlak. Ketiga materi tersebut diperkenalkan secara terpisah, kurang mendalam dan sulit memberikan persepsi yang jelas kepada mahasiswa tentang agamanya sendiri. Adapun materi-materi program Pencerahan Kalbu disusun dan diformulasikan dalam satu konsep materi ajar yang terpadu dan terjalin dalam satu keterkaitan sinergitas antar tiga konsep agama tersebut.

Lebih lanjut Abd. Rahim Amin menjelaskan, Pencerahan Kalbu yang merupakan program pembinaan khusus untuk seluruh mahasiswa baru UMI pada hakikatnya adalah pendidikan yang bernuansa sufistik. Dengan kata lain, metode dan pendekatan sufistik merupakan unsur utama dan ciri khas pokok pada program Pencerahan Kalbu tersebut. Hal itu didasarkan pada dua konsepsi dasar, yaitu : (a) Dalam Pencerahan Kalbu, misi dan target utama adalah percepatan penyadaran dan penanaman (internalisasi) nilainilai agama, khususnya akhlak, pada jiwa peserta. Tentunya kedua proses tersebut lebih terfokus dan terkonsentrasi pada aspek ruhani dibanding aspek akal kognitif mahasiswa. (b) Program tersebut lebih menekankan pengembangan dan pembinaan aspek SDM mahasiswa yang bersifat non-fisik, yaitu sumber daya ruhaniahnya. Dengan kegiatan zikir secara intensif dan rutin diharapkan terjadi perubahan dan kestabilan jiwa, dan pada gilirannya memudahkan bagi para dosen pembimbing untuk mengarahkan serta mengembangkan potensi sumber daya tersebut.

Jelasnya, segala bentuk pendidikan dan bimbingan yang menyentuh aspek batin serta bertujuan membina dan mengembangkan aspek tersebut dapat dikatakan sebagai satu bentuk pendidikan dalam pendekatan sufistik. Dan UMI, sebagai Perguruan Tinggi Agama Islam yang mencurahkan perhatian besar 
pada peningkatan SDM mahasiswa, khususnya SDM non-fisiknya, memberikan respon positif dan berjuang untuk menyukseskan pelaksanaan program tersebut.

Keanekaragaman latar pendidikan dan kondisi sosial mahasiswa baru sebagai in-put mendorong para pembina untuk menetapkan pencapaian tujuan program dalam tiga hal, yaitu: (1) Penyamaan persepsi dasar; setiap mahasiswa baru tentunya memiliki persepsi-persepsi dasar yang berbeda-beda tentang ajaran agama yang mereka anut. Keanekaragaman tersebut lebih banyak diakibatkan dari perbedaan tingkat pendidikan dasar yang mereka terima, baik di sekolah maupun di rumah. Pencerahan Kalbu berupaya memberikan pemahaman dasar tentang ajaran agama Islam, baik yang berkaitan dengan akidah, syariah ataupun akhlak. (2) Memberikan gambaran tentang eksistensi ilmu dalam Islam. Sebagian besar mahasiswa baru diasumsikan memiliki persepsi dualistik, yaitu adanya dikotomi antara ilmu agama dan ilmu umum. Dengan Pencerahan Kalbu diupayakan dan diharapkan mereka nantinya menemukan gambaran jelas tentag keterkaitan ilmu dan agama. Agama adalah seperangkat nilai yang mendasari pengembangan ilmu pengetahuan, yang dalam istilah teknisnya disebut dengan Islamisasi ilmu pengetahuan. (3) Memberikan kesiapan mental dalam menerima ilmu pengetahuan secara islami. Hal ini merupakan modal awal bagi mereka sebagai mahasiswa muslim di dalam lingkungan kampus islami. Yang perlu dicatat di sini bahwa UMI menganut budaya keilmuan yang bercirikan Islam. Epistemologi keilmuan diupayakan tetap dalam batasan-batasan dan nuansa keislaman yang khas.

Pendidikan yang dilaksanakan UMI, dalam pandangan H. Zein Irwanto, Direktur Pesantren, pada dasarnya bertujuan membentuk tiga kecerdasan, yaitu kecerdasan intelektual yang dilaksanakan secara reguler di kampus I dan II di Makassar, dan kecerdasan moral serta spiritual yang dilaksanakan di kampus Pesantren Mahasiswa di Padang Lampe. Kesemuanya itu - secara sinergi dan terpadu- bertujuan membentuk sarjana muslim yang intelek, beramal saleh dan berakhlakul karimah. 
Idealnya, menurut beliau, seorang sarjana muslim memiliki potensi-potensi serta kemampuan dasar yang kelak dapat memberikan kesejahteraan bagi dirinya serta membuka kesempatan bergerak secara leluasa dalam memajukan agama dan bangsanya. Seorang sarjana UMI yang ideal memiliki kemampuan bahasa asing yang baik, inggeris atau Arab, memiliki dasar-dasar ilmu keislaman serta profesional dalam ilmu-ilmu yang menjadi bidang spesialisasinya.

Idealisme tersebut telah sejak lama merupakan ruh yang melandasi misi dan tujuan pendidikan di UMI. Namun yang menjadi kendala utama adalah sarana pendidikan, baik yang bersifat fisik maupun non-fisik, yang belum memadai untuk mewujudkan idealisme tersebut. Dengan keberadaan Pesantren Mahasiswa di Padang Lampe, UMI kembali merintis program unggulan pembinaan tradisi keilmuan islami sebagai bagian dari upaya penciptaan sarjana muslim yang ideal.

\section{Pencerahan Kalbu sebagai Metode Tasawuf Amali}

Memperhatikan aktvitas pendidikan di Pesantren Mahasiswa UMI Dar al-Mukhlisin Padang Lampe, tergambar kesan bahwa metode yang dipergunakan para pembina Pesantren adalah perpaduan dari metode kepesantrenan konvensional dan metode yang diadopsi dari tradisi keilmuan para ulama Salaf. Dijelaskan oleh Zein Irwanto, tradisi kepesantrenan yang diaplikasikan di pesantren tersebut secara terperinci dilakukan dalam tiga metode, yaitu : 1) Metode Muzammil, yaitu metode pendidikan yang diterapkan Allah swt terhadap Rasulullah saw. 2) Metode Dar al-Arqam, yaitu metode pendidikan dan dakwah yang diterapkan Rasulullah pada masa awal pembentukan komunitas muslim di Mekah. Metode ini dipandang sangat berhasil menanamkan pondasi keimanan dan ketauhidan serta semangat jihad pada diri generasi pertama Islam. Metode ini menekankan proses internalisasi nilai-nilai agama secara intensif dalam kelompok yang diikat oleh rasa persaudaraan yang sangat kuat. 3) Metode Jama'ah yang diilhami dari surah al-Fatihah. Metode ini menekankan aspek kebersamaan dalam segala hal. Para peserta dididik untuk memahami dan mengapresiasi nilai kebersamaan dalam kegiatan ibadah, belajar-mengajar, makan dan sebagainya. 
Selanjutnya beliau menjelaskan bahwa metode pembinaan yang dilaksanakan dalam program ini secara keseluruhan menggunakan pendekatan-pendekatan paedagogis yang 'mengadopsi' konsep-konsep sufistik. Pendekatan tersebut, oleh para pembinanya, disebut dengan pendekatan Sufistik Tasawuf

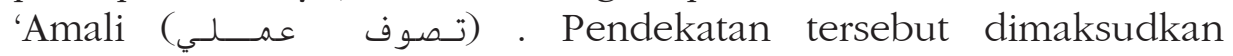
sebagai pendekatan yang menggunakan metode tasawuf dalam hal pembinaan aspek batiniah, tapi bukan ditujukan untuk mengarahkan peserta untuk mencapai target-target sufisme ( maqam dan ahwal) yang cenderung eksklusif dan subyektif. Dalam batasan amaliahnya, pendekatan sufistik bertujuan memberikan pembinaan dan bimbingan kesufian kepada para peserta agar mereka mampu memahami mengamalkan nilai-nilai akhlakul karimah yang terlahir dari kebersihan jiwa sebagai hasil dari proses Pencerahan Kalbu.

Pendekatan Sufistik 'Amali merupakan konsepsi kesufian yang dibangun dan diamalkan oleh Imam al-Ghazali. Berbeda dengan para ulama Sufi lainnya, al-Ghazali tidak mementingkan aspek pencapaian "orgasme spiritual" yang tersimbolisasi dengan tahapan-tahapan maqamat dan ahwal, sebagaimana yang teraplikasi pada praktek-praktek kesufian dalam kehidupan mayoritas ulama sekaliber Dzun Nun al-Mishri, Hasan al-Bashri, al-Junaid dan lain-lain. Dalam konsep Mujahadah, Riyadlah, Mubasabah dan Muraqabah-nya yang cenderung lebih praktis-aplikatif, al-Ghazali lebih mengedepankan pencapaian tujuan pembentukan akhlak muslim yang sebenarnya dengan berporos pada kepribadian Rasulullah saw. sebagai uswatun hasanah.

Secara mendasar, konsep Tasawuf 'Amali mengajarkan bahwa untuk mencapai tingkat kesempurnaan dan kesucian jiwa memerlukan pendidikan dan latihan mental yang panjang. Oleh karena itu pada tahap pertama teori dan amaan tasawuf diformulasikan kepada pengaturan sikap mental dan pendisiplinan tingkah laku yang ketat. Dengan kata lain, untuk dapat berada di hadirat Allah dan sekaligus mencapai tingkat kebahagiaan yang optimal manusia harus lebih dulu mengidentifikasikan eksistensi dirinya dengan ciri-ciri ke-Tuhanan melalui pensucian jiwa raga yang bermula dari pembentukan pribadi yang bermoral paripurna dan berakhlak mulia (Said, 1983: 96). 
Aktivitas kehidupan sufistik memang dirancang khusus untuk membina dan memberikan perubahan radikal pada mahasiswamahasiswi UMI yang sepanjang umurnya belum pernah sama sekali tersentuh oleh pembinaan agama secara intensif. Khususnya lagi, banyak diantara mereka berlatarbelakang keluarga berada dan kurang mendapat pembinaan keagamaan dari keluarga mereka sendiri. Pada intinya, program Pencerahan Kalbu, dengan segenap perangkat, kurikulum, peraturan dan strategi pendekatan pedagogisnya, ditujukan untuk memberikan gambaran dan pengetahuan kepada mahasiswa bagaimana seharusnya menjalankan ajaran agama dan manfaat positif dari ketaatan menjalankan ibadah serta pengamalan nilai-nilai akhlak karimah.

Setiap gelombang mahasiswa yang datang secara bergilir ke Padang Lampe dibagi dalam 8 atau 12 kelompok, yang masing-masing kelompok dibina dan diawasi langsung dua orang dosen/ustaz atau uztazah selaku wali kelas. Secara intens selama berada dalam pesantren mereka dididik dan dibimbing oleh wali kelasnya mulai dari penempatan asrama, pemahaman tentang peraturan pesantren, kontrak belajar, amalan-amalan yang harus dijalankan hingga memperhatikan kondisi fisik-psikis mereka selama menjalani program. Selain bentuknya sebagai kelas belajar reguler, kelompok-kelompok belajar itu sendiri pada saat-saat tertentu beralih menjadi kelompok halaqah dalam kegiatan zikir dan tadarus.

Halaqah secara etimologis bermakna lingkaran yang berantai. Dalam konteks Pencerahan Kalbu, halaqah dipahami dan diaplikasikan sebagai kelompok yang terdiri dari beberapa orang yang berkumpul secara melingkar dalam majlis dan melaksanakan kegiatan-kegiatan yang diprogramkan secara bersama dalam jalinan komunikasi dan inter-relasi yang erat. Pada banyak kasus, halaqah ini memberikan pengaruh positif terhadap hubungan antar anggota, yaitu terciptanya rasa persaudaraan, silaturrahim dan solidaritas yang tinggi meski mereka berasal dari fakultas-fakultas yang berbeda. Spirit dari halaqah ini tenyata berlanjut dan mewarnai kehidupan mereka di kampus pasca program Pencerahan Kalbu. 
Rutinitas kesufian dimulai dari jam 3.00 dini hari dan berakhir pada pukul 22.00 malam hari. Secara kasat mata, bentuk pembinaan kesufian yang diterapkan pada program ini cenderung terkesan menyiksa dan membebani para peserta. Kesan tersebut terlihat pada hari-hari pertama mereka menjalani program. Meski demikian, kegiatan dan rutinitas yang harus dijalani tersebut pada hakikatnya merupakan latihan dan tempaan kejiwaan yang diharapkan akan berdampak positif pada kepribadian peserta.

Tepat pada pukul 3.00 dini hari, para peserta dibangunkan secara serentak dan diarahkan ke mesjid untuk melaksanakan shalat tahajjud secara berjamaah dengan dipimpin oleh salah seorang guru pembina. Meski shalat tahajjud sendiri adalah shalat sunnat, namun dalam konteks kepesantrenan sebagaimana yang diterapkan dalam Pencerahan Kalbu shalat tahajjud secara berjamaah menjadi wajib. Hal ini ditujukan agar para mahasiswa lebih mengenal dan meresapi efek-efek spiritual dari ibadah tersebut.

Setelah shalat tahajjud yang dilakukan sebanyak delapan rakaat, para peserta dikumpulkan dalam satu majlis dalam halaqah masing-masing untuk melakukan tadarus al-Qur'an hingga masuk waktu subuh. Adapun materi tadarus adalah surah-surah pendek pada akhir juz Amma, dimulai pada surah al-Nas. Kegiatan tadarus al-Qur'an tidak semata memberikan bimbingan tentang cara membaca (tajwid) yang benar, namun lebih dari itu mereka diharuskan menghafal setiap surah yang telah ditadarruskan pada hari itu. Dalam tempo satu bulan diupayakan setiap peserta telah mampu membaca sekaligus menghafal surah-surah pendek alQur'an.

Setelah shalat Subuh, kegiatan dilanjutkan dengan zikir bersama dalam satu halaqah besar. Seluruh peserta duduk dalam posisi setengah melingkar mengitari seorang ustaz yang bertugas memimpin dan membimbing zikir bersama tersebut. Untuk memudahkan pelaksanaan zikir, setiap peserta telah diberikan buku panduan zikir lengkap dengan terjemahannya, sehingga mereka dapat memahami makna bacaan-bacaan yang dilantunkan tersebut (lihat foto I pada lampiran) 
Kegiatan zikir tersebut berlangsung hingga pagi, atau tepatnya masuk waktu shalat Dluha. Kegiatan zikir diakhiri dengan melaksanakan shalat dluha secara berjamaah dan peserta kembali ke asrama untuk beristirahat dan menyiapkan diri memasuki kegiatan perkuliahan di kelas. Proses belajar di kelas berlangsung hingga menjelang duhur, dan mereka kembali diarahkan ke mesjid untuk melaksanakan shalat Duhur secara berjamaah.

Satu hal yang unik, yaitu setiap selesai membaca wiridan ba'da shalat salah seorang ustaz berdiri dan menyampaikan satu atau dua hadis. Hadis-hadis yang disampaikan adalah hadis-hadis pendek yang populer dan berkaitan dengan tema-tema akidah, ibadah, akhlak serta perilaku Rasulullah saw. Dan biasanya setiap hadis yang telah dibacakan ditulis oleh setiap peserta sebagai koleksi atau khazanah pengetahuan keislaman yang akan mereka bawa pulang.

Menjelang shalat Asar, peserta kembali menuju ke mesjid untuk melaksanakan shalat asar secara berjamaah. Setelah itu, mereka mengikuti kuliah sore berupa pengajian umum dalam halaqah besar. Materi-materi yang disampaikan mencakup pemahaman tentang konsep-konsep dasar Pencerahan Kalbu, dasar-dasar Tasawuf, pemahaman tentang metode dan manfaat zikir, pengetahuan akhlak dan Nasyid. Kegiatan sore juga kadang berbentuk permainan (game) yang diformat khusus untuk diterapkan dalam program Pencerahan Kalbu.

Dalam kegiatan sore ini, peserta juga diarahkan untuk berinteraksi dengan fenomena-fenomena alam sekitar dengan pendekatan Tadabbur alam. Pada materi ekstra yang dilakukan di luar kelas ini peserta berupaya memahami serta merenungi fenomena-fenomena alam, yang memang suasana dan kondisi alam di Padang Lampe cukup kondusif untuk hal tersebut, dan mengaitkan fenomena alam tersebut dengan kebesaran dan keMaha Kuasa-an Allah swt. di samping itu, dengan interaksinya dengan alam luar peserta dapat menyadari posisinya sebagai bagian dari alam ciptaan Allah dan menyadari bahwa betapa kecilnya diri manusia jika dibandingkan dengan segala ciptaanNya. 
Setelah shalat Magrib, para peserta kembali berkumpul di dalam halaqah besar untuk mengikuti pembacaan Yasin Fadhilah dan dilanjutkan dengan zikir bersama hingga Isya. Perlu dijelaskan bahwa Yasin Fadhilah adalah surah Yasin yang dilengkapi dengan do'a-do'a khusus. Keberadaan do'a khusus yang dibaca di tengah-tengah surah Yasin dilatarbelakangi keyakinan bahwa semua do'a yang dibaca bersama surah Yasin pasti dikabulkan Allah.

Setelah makan malam, para peserta kembali memasuki kelas masing-masing untuk menerima materi do'a dan wirid. Pada materi tersebut mereka diberikan bimbingan tentang fadlilah (keutamaan) doa-doa tertentu serta diajarkan bentuk-bentuk dan bacaan-bacaan wirid untuk diamalkan sehari-hari. Dalam hal ini peserta diharuskan menghafal beberapa doa dan bacaan-bacaan shalat, baik dalam shalat maupun setelah shalat. Kelas ini berlangsung hingga kurang lebih pukul 21.00 wita.

Pada saat istirahat malampun, para pembina tetap melakukan kontrol dan pembinaan terhadap perilaku-perilaku peserta yang seringkali masih terpengaruh kehidupan kota. Peserta program yang juga adalah mahasiswa baru dianggap belum sepenuhnya mampu berpisah dengan kehidupan dan pergaulan malam yang identik dengan kehidupan metropolitan. Karena itu, mereka tetap mendapat pengawasan ketat untuk tidak berbuat dan bertingkah laku di luar batas kewajaran sebagai warga pesantren. Tepat pukul 22.00 seluruh peserta diharuskan berada di dalam kamar masing-masing dan beristirahat dengan cukup agar mereka dapat dibangunkan dan kembali memulai aktivitasnya pada pukul 3.00 dini hari nantinya.

Satu hal yang menarik dan cukup unik dari segenap kegiatan yang diprogramkan di Pesantren Padang Lampe ini, yaitu acara makan bersama dengan gaya 'usrab'. Dapat dirasakan bahwa hampir seluruh aktivitas yang dilakukan para peserta selama berada di dalam kampus Pesantren diwarnai dan diarahkan pada pencapaian targettarget pendidikan akhlak yang berciri khas sufistik. Tak ketinggalan kegiatan makan bersama, tak luput dari warna atau corak yang didasari oleh nilai-nilai sufistik. 
Dengan penjatahan dan pengaturan makanan tersebut dapat terbina dua sikap positif, yaitu:

a.) Persaudaraan, keakraban dan sikap tenggang rasa sesama teman sehingga setiap orang tidak mengganggu porsi atau hak orang lain. Setiap kelompok menikmati makanan secara bersama dengan menerima keberadaan orang lain bersama mereka.

b.) Kesabaran dan sikap qana'ah dengan menerima makanan yang sangat sederhana tersebut dengan senang hati. Mereka 'dipaksa' untuk puas dengan apa yang disediakan oleh pihak pesantren. Dengan demikian mereka terlatih untuk menerima penderitaan sekaligus tetap menjaga hubungan sosial mereka dengan orang lain.

Keseluruhan kegiatan yang diprogramkan, mulai dari bangun dan bertahajjud di waktu dini hari hingga kegiatan makan di atas nampan secara bersama, secara sinergi merupakan rangkaian proses latihan kerohanian. Dalam penjelasannya, Zein Irwanto, selaku Direktur dan sekaligus instruktur utama, menekankan bahwa bentuk-bentuk latihan dan pembiasaan yang relatif cukup berat dalam skala awam itu merupakan mujahadah dan riyadhah bagi mereka (lihat Armstong, 1996: 190 \& 241). Dan memang, menurut beliau, ke-berhasilan dalam program Pencerahan Kalbu sangat bertumpu pada keberhasilan peserta dalam menempuh proses mujahadah dan riyadhah tersebut.

Dalam konteks Pencerahan Kalbu, seperti yang diungkapkan Zein Irwanto, Tajalli merupakan ekspresi kesadaran diri yang mendalam dari hasil segenap mujahadah dan riyadlah yang telah dilaluinya. Pada kurang lebih sepuluh hari terakhir terjadi perubahan sikap dan image peserta terhadap kegiatan rutinitas sufistik itu sendiri. Pada awalnya mereka bersikap acuh tak acuh dan kurang memperdulikan materi-materi dan kegiatan yang dilaksanakan. Bahkan seringkali memberontak dan menolak segala macam ikatan atau aturan-aturan kepesantrenan. Namun hari-hari terakhir mereka berubah sikap dan cenderung menikmati rutinitas kegiatan yang mereka jalani. 
Ekspresi dari munculnya Tajalli pada diri peserta yaitu ketika mereka menangis berlinang air mata dalam zikirnya. Tetesan air mata tersebut dapat dijadikan bukti bahwa peserta tersebut telah mencapai tahapan kesadaran internal yang tidak mudah digambarkan dengan kata-kata. Ekspresi Tajalli pada setiap peserta tidak terjadi pada waktu yang bersamaan. Beberapa orang justru telah memperlihatkan gejala-gejala Tajalli pada hari-hari pertama pelaksanaan program, meski sebagian besar baru tampak pada akhir-akhir kegiatan.

Hal yang paling penting dari pencapaian tersebut, sebagaimana yang dijelaskan oleh Abd. Rahim Amin, adalah terbangunnya komitmen kesadaran spiritual yang menjadi dasar langkah mereka dalam menjalani kehidupan. Komitmen untuk senantiasa memelihara kecerahan hati serta bersikap dan berperilaku sesuai dengan suara hati nurani mereka yang telah disinari oleh cahaya zikir.

Untuk mengatasi persoalan premanisme dan tawuran, UMI secara terprogram mengirim mahasiswa-mahasiswa yang dianggap merupakan biang keributan di kampus ke Pesantren. Pada beberapa kasus ditemukan pula beberapa mahasiswa pecandu narkoba yang membutuhkan terapi khusus. Sejauh pengamatan peneliti, Pencerahan Kalbu, dengan kegiatan wirid dan zikirnya, cukup memberikan pengaruh positif pada kesadaran mereka tentang nilai-nilai kebaikan. Khusus pecandu narkoba, secara berangsur-angsur dalam tempo yang tidak lama mereka telah mampu melepaskan diri dari ketergantungan kepada benda-benda haram tersebut.

Fenomena zikir merupakan fenomena yang cukup unik dan menarik untuk diteliti. Pembacaan zikir dengan suara keras (jahr) dan berirama merupakan salah satu keunikannya. Para peserta setiap subuh dan magrib berkumpul dalam bentuk majlis yang mengelilingi seorang 'mursyid' atau yang bertugas memimpin zikir. Mursyid membacakan bacaan-bacaan zikir dengan irama yang sangat menyentuh dan diikuti oleh seluruh peserta. Metode zikir ini memang tidak lazim dipraktekkan, namun meski demikian hal ini ditujukan, di samping untuk memperkenalkan cara dan bacaan 
zikir kepada para peserta sebagai pemula, juga dengan cara jabr tersebut diharapkan lebih menyentuh dan bisa 'dinikmati' oleh mereka.

Tegasnya, program Pencerahan Kalbu secara umum merupakan rangkaian kegiatan yang secara terpadu berupaya mensosialisasikan zikir agar menjadi satu kebiasaan dan kebutuhan dalam kehidupan mahasiswa, sehingga dengan demikian fungsi zikir sebagai sarana penenteraman dan penenangan jiwa dapat terwujud dan dirasakan oleh setiap warga kampus. Di samping itu, zikir pun dapat menjadi terapi kejiwaan yang diharapkan mampu menjadi solusi yang efektif dalam mendidik dan memperbaiki moral dan perilaku generasi muda yang cenderung menyimpang.

\section{Kesimpulan}

Berdasarkan hasil pembahasan terdahulu, maka dapat dikemukakan beberapa kesimpulan sebagai berikut: (1) Pendidikan Islam tidak hanya mengupayakan pengembangan potensi fisik-kognitif semata, tapi lebih dari itu pendidikan Islam sangat menekankan pengembangan dan peningkatan potensi (SDM) batiniah, yaitu dimensi spiritual yang merupakan unsur penting dalam pembentukan kepribadian manusia. Secara historis dan teoretis, konsep-konsep tasawuf (Sufistik) memiliki relevansi dengan pendidikan Islam, khususnya yang berkaitan dengan pendidikan moral sebagai sarana pembentukan karakter moralitas yang efektif. (2) Pendekatan sufistik dalam sistem pembinaan di Pesantren Dar al-Mukhlisin Padang Lampe UMI diterapkan dalam program kegiatan yaitu, penerapan Tasawuf 'amali yang diaplikasikan dalam tiga tahapan pembinaan, yaitu Takhalli, Tahalli dan Tajalli, pembinaan dan pembiasaanpembiasaan baik melalui latihan-latihan kejiwaan, yaitu melalui Mujahadah dan Riyadhah, penerapan metode zikir secara rutin dan intensif dengan tujuan memberikan penyadaran serta 
menumbuhkan muhasabah (instrokpeksi diri ) dan muraqabah (kedekatan dan pengawasan Allah) dalam jiwa peserta, serta pemberian materi-materi keagamaan yang meliputi materi akidah, syariah dan akhlak. Ketiga materi tersebut diberikan kepada peserta secara terpadu dan sinergi yang mengarah kepada pencapaian pemahaman tentang dimensi spiritual ajaran Islam, sekaligus pembentukan kesadaran dan kemauan untuk mengamalkan seluruh ajaran agama Islam dengan komitmen dan konsisten.

\section{Daftar Pustaka}

Abdullah, M. Amin, 1998. Problem Epistemologis-Metodologis Pendidikan Islam, dalam Abd. Munir Mulkhan et al., Religiusitas Iptek, Yogyakarta: Pustaka Pelajar,

Arifin, H.M, 2000. Filsafat Pendidikan Islam, Jakarta: Bumi Aksara,.

Armstrong, Amatullah, 1996, Khazanah Istilah Sufi; Kunci Memasuki Dunia Tasawuf, Bandung; Mizan,.

Budiman, Nasir. 2001. Pendidikan dalam Perspektif Al-Qur'an, Jakarta: Madani Pres,.

Madjid, Nurcholish. 2000. Masyarakat Religius, Membumikan NilaiNilai Islam dalam Kehidupan Masyarakat, Jakarta: Paramadina,.

Mahjub, Abbas. 1987. Ushul al-Fikr al-Tarbawi fi al-Islam, Beirut: Dar Ibn Katsir,.

Mastuhu, Dinamika.1994. Sistem Pendidikan Pesantren, Jakarta: Inis,

Muhaimin, et.al. 2002. Paradigma Pendidikan Islam,Bandung: Remaja Rosdakarya,.

Said, Usman et. al. 1983. Pengantar Ilmu Tasawuf, Jakarta: Direktorat Pembinaan Perguruan Tinggi Agama Islam,. 
Steenbrink, Karel A. 1984. Pesantren, Madrasah, Sekolah, Jakarta: LP3ES, .

Syukur, Amin 2001. (ed), Tasawuf dan Krisis, Yogyakarta: Pustaka Pelajar. 